\title{
NEUROSYPHILIS IN ANGLO-AMERICAN COMPOSERS AND JAZZ MUSICIANS
}

\author{
Darko Breitenfeld ${ }^{1}$, Davor Kust ${ }^{2}$, Tomislav Breitenfeld ${ }^{3}$, Marin Prpić ${ }^{2}$, Marko Lucijanić ${ }^{4}$, \\ Davor Zibar ${ }^{5}$, Vedran Hostić ${ }^{6}$ Maja Franceschi ${ }^{2,7}$ and Ante Bolanča ${ }^{2}$
}

${ }^{1}$ Croatian Physicians Music Society; ${ }^{2}$ Clinical Department of Oncology and Nuclear Medicine, Sestre milosrdnice University Hospital Center, Zagreb, Croatia; ${ }^{3} \mathrm{Clinical}$ Department of Neurology, Sestre milosrdnice University Hospital Center, Zagreb, Croatia; ${ }^{4} \mathrm{Clinical}$ Department of Internal Medicine, Dubrava University Hospital, Zagreb, Croatia; ${ }^{5}$ Department of Obstetrics and Gynecology, The Rotunda Hospital,

Dublin, Republic of Ireland; ${ }^{6}$ Clinical Department of Anesthesiology, Resuscitation and Intensive Care, Sestre milosrdnice University Hospital Center, Zagreb, Croatia; ${ }^{7}$ School of Medicine, University of Zagreb, Zagreb; School of Medicine, Josip Juraj Strossmayer University of Osijek, Osijek, Croatia

SUMMARY - Syphilis is a sexually transmitted, systemic disease caused by the spirochete bacterium Treponema pallidum. The most common mechanism of transmission is sexual intercourse. Although there are several hypotheses, the exact origin of the disease remains unknown. Newly published evidence suggests that the hypothesis supporting the theory of the American origin of the disease is the valid one. Among 1500 analyzed pathographies of composers and musicians, data on ten Anglo-American composers and jazz musicians having suffered from neurosyphilis (tertiary stage of the disease) were extracted for this report. In this group of Anglo-American composers and musicians, most of them died from progressive paralysis while still in the creative phase of life. Additionally, diagnoses of eleven other famous neurosyphilitic composers, as well as basic biographic data on ten less known composers that died from neurosyphilis-progressive paralysis are also briefly mentioned. In conclusion, neurosyphilis can cause serious neurological damage, as well as permanent disability or death, preventing further work and skill improvement.

Key words: Neurosyphilis; Syphilis; History; Music; Biography as topic; Pathology

\section{Introduction}

Syphilis is a sexually transmitted, systemic disease caused by the spirochete bacterium Treponema pallidum (T. pallidum). The bacterium thrives in moist environment, so continuous moisture is a prerequisite for transfer of the microorganism from one person to another. The most common mechanism of transmission is sexual intercourse. Occasionally, the disease can also be acquired by direct nonsexual contact with the in-

Correspondence to: Davor Kust, $M D, P h D$, Clinical Department of Oncology and Nuclear Medicine, Sestre milosrdnice University Hospital Center, Vinogradska c. 29, HR-10000 Zagreb, Croatia E-mail: davor.kust@gmail.com

Received January 4, 2017, accepted April 13, 2017 fected person, and by vertical transfer from the mother to the fetus (resulting in congenital syphilis).

\section{Origin of the disease}

Although there are several hypotheses, the exact origin of the disease is still unknown ${ }^{1}$. One hypothesis proposes that syphilis was transferred to Europe by the crew of Christopher Columbus, after his expeditions to the Americas in the late $15^{\text {th }}$ century. Some other hypotheses claim that the disease already existed in Europe at the time (mutation of another treponematosis), but went unrecognized, or that syphilis was transported from the Old to the New World ${ }^{2}$. Newly published evidence suggests that the hypothesis supporting the theory of the American origin of the dis- 
ease is the valid one. Skeletal lesions characteristic of the diagnosis of syphilis, which had been identified in various areas throughout the American continent plead for syphilis existence in these areas before $\mathrm{Co}^{-}$ lumbus discovered America, and radiocarbon dating of the bone fragments showed the age of several thousand years ${ }^{3}$. On the other hand, evidence in Europe could not support the existence of syphilis in the preColumbian period.

\section{Spread of the disease in Europe and other parts of the world}

It is theorized that members of Columbus first expedition to the America were exposed to the disease through sexual intercourse with the native people. The first recorded instance of syphilis in Europe was recorded in 1494, soon after return of Columbus' crew, when it ravaged the French troops and their Spanish allies that were besieging the city-state of Naples (Italian War of 1494-1498), as well as the prostitutes who accompanied them. Due to being spread by French troops, it was initially known as the "French disease" or "Naples disease". From that area, syphilis spread to whole Europe, and beyond (Germany and Switzerland in 1495; England and Holland in 1496; India in 1498, transmitted by Vasco da Gama's crew; China and Japan in 1505). After the discovery by the American physician John Friend Mahoney (and others) around 1943, showing that penicillin was an effective treatment for syphilis, the number of cases of the disease has declined considerably, particularly in developed countries. In the United States, similar to other parts of the world, syphilis emerged as a major public health concern in the late $19^{\text {th }}$ and early $20^{\text {th }}$ century ${ }^{4}$. Composers who developed neurosyphilis earlier, between the $18^{\text {th }}$ and late $19^{\text {th }}$ century, and especially from the $16^{\text {th }}$ to $18^{\text {th }}$ century, could not be definitively diagnosed.

\section{Stages and treatment of the disease}

The symptoms of syphilis are highly variable. The spirochete multiplies at the initial site of entry and a characteristic primary lesion, called the chancre, forms approximately 3 to 90 days (average 21 days) after the initial exposure at the point of contact. The exudate from the chancre is highly infectious, and lymph node enlargement frequently occurs around the area of infection. The primary lesion usually heals within 3 to 6 weeks and leaves no scar. Secondary stage of the disease usually occurs 4 to 10 weeks after primary infection, and is characterized by a flu-like illness, which sometimes results in spontaneous resolution. However, in some individuals, generalized skin rash may develop and these patients are highly infectious. Disease can also affect mucous membranes and lymph nodes. Finally, T. pallidum disappears from secondary lesions and skin rash. Tertiary syphilis develops 3 to 15 years after the initial infection, and is caused by spread of the bacterium to other parts of the body, in particular the skin, mucous membranes, liver, eyes, joints, bones, muscles, cardiovascular system, or central nervous system (referred to as neurosyphilis). Subsequently, the course of the disease is highly variable ${ }^{5}$. None of these tertiary lesions will spontaneously heal. Neurosyphilis may occur early, being either asymptomatic or in the form of syphilitic meningitis, or late as meningovascular syphilis, general paresis, or tabes dorsalis, a condition where the spinal column is affected. The prognosis of syphilis varies with promptness of diagnosis and treatment. In the $20^{\text {th }}$ century, using the potassium iodide, mercurial and arsenic compounds, and penicillin after 1943, the syphilis mortality has dramatically dropped. Nowadays, it is successfully treatable with penicillin or other antibiotics such as tetracycline or erythromycin at any stage, however, curing late-stage syphilis cannot repair already present neurological or other damages caused by the disease.

\section{Methods}

Pathographies of 1500 famous musicians and composers were analyzed to find those with proven or clinically highly suspected (in composers and musicians who lived before the era of diagnostic tests for syphilis, especially when the existence of the oligosymptomatic, variable and deceptive aspects of neurosyphilis is taken into account) diagnosis of neurosyphilis $^{6}$.

\section{Results}

Considering the American origin of the disease, this article presents pathographies of the most eminent Anglo-American composers and jazz musicians - neurosyphilitics (MacDowell, Joplin, Jackson, Bold- 
en, Chauvin, Razaf, Smith, Roppolo, Young, and Parker), as well as some other famous musicians who died from neurosyphilis.

\section{Anglo-American classic composers and jazz musicians}

Edward Alexander MacDowell (December 18, 1860 - January 23, 1908) was an American composer and pianist born in New York, where he spent greater part of his life ${ }^{7,8}$. He lived very dynamically, which led him to a serious road traffic accident in 1904 . He was run over by a hansom cab, wheels passed over his neck and injured spinal nerves. Although some scholars theorize that he died due to consequences of this traffic accident or bromide poisoning (later emerged a theory based only on described symptoms), several other believe that MacDowell contracted syphilis and the disease caused his death ${ }^{9}$. First definitive signs of mental illness appeared at the end of 1904, resulting in regression to a childlike state with short periods of fruitful creativity. According to this theory, his syphilis progressed to terminal stage with signs of late complications of progressive paralysis. He also suffered from dementia, aphasia, and locomotor ataxia. Most medical notes of that period were kept by Anna Betz, MacDowell's nurse. She noted the following symptoms: fever, inability to walk, chronic stomach distress, bronchial problems, weak heart, seizures with twitching, swelling of the legs and the right hand, delusions of grandeur, and grinding his teeth. From time to time, he was depressive, occasionally having suicidal ideas. Paranoia also appeared as a sign of terminal stage of syphilis. Considering the fact that there was no cure for syphilis at that time, he died early, at the age of 48 . In death certificate, later discovered by Margery Lowens, "paresis - dementia paralytica" (which is commonly associated with neurosyphilis) was stated by Dr. Loomis L. Danfort as the cause of death. MacDowell's wife Marian kept this diagnosis from the press, guarding her husband's reputation, so this may be the reason that syphilitic theory of MacDowell's death is not so widespread.

Scott Joplin (c. 1967/1868 - April 1, 1917) was an American jazz musician and pianist ${ }^{10}$. Joplin achieved fame for his ragtime compositions, which earned him reputation as the 'king of ragtime writers'. Already as a child, he demonstrated extraordinary musical talent, and learned to play banjo and piano. He was infected with syphilis in his youth, around 1894. Throughout his life, he was promiscuous and had married several times. First signs of neurosyphilis appeared in 1904. From 1907 onwards, progressive paralysis (general paresis) was progressing fast. In 1916, he descended into dementia. He was hospitalized in a mental institution several times, last time in January 1917, and he died there three months later.

Antonio (Tony) Junius Jackson (October 25, 1882 April 20,1921) was arguably the best piano player of the Storyville era ${ }^{10}$. His incredible skill at improvisation served as a role model for many musicians of the time. Privately, he was promiscuous, homosexually oriented alcoholic with liver cirrhosis and epilepsy. There are several reports that he contracted syphilis early in life and developed progressive paralysis with mental disorders and dementia, although many of these symptoms may have been exacerbated by his epileptic seizures. Over time, his voice and physical strength became impaired by the disease but he continued to work. Finally, liver failure due to cirrhosis was the most probable direct cause of death.

Charles Joseph 'Buddy' Bolden (September 6, 1877 November 4, 1931) was an American jazz musician and wind instrumentalist, one of the key figures in the development of Jass rag-time music, which later came to be known as jazz ${ }^{10}$. He was heavy alcohol abuser, which culminated in 1907 during New Orleans Labor Day parade, when he had an episode of acute alcoholic psychosis. He was hospitalized but his hallucinations and violence worsened, and he spent the last 25 years of life in a mental institution. Many theories have been offered concerning Bolden's mental illness, including alcoholism, neurosyphilis, schizophrenia, and more recently also Meniere's disease, although none has been conclusive.

Louis Chauvin (March 13, 1881 - March 26, 1908) was an American jazz musician, pianist and compos$\mathrm{er}^{10}$. He was another heavy alcohol abuser who contracted the disease very early in his life. Infection progressed to progressive paralysis. At the end of his life, he was mentally disturbed, psychotic and demented, with the diagnosis of multiple areas of syphilitic changes. His death certificate lists causes of death as "multiple sclerosis, probably syphilitic", and starvation due to coma, although some other theories have been proposed later, such as sickle cell anemia, a disease more common in black men at that time. Unfortu- 
nately, he did not live long enough to make any phonograph recordings.

Andy Razaf (December 16, 1895 - February 3, 1973) was an American poet and jazz musician, one of the most accomplished and influential lyricists of his time ${ }^{10}$. He claimed to have written his first poem at the age of 10 , and his last song was published only several months before his death. He contracted syphilis in 1951, and the infection progressed to tabes dorsalis, with walking difficulties, weakness and ataxia. For 20 years, he was bounded to a wheelchair, with such severe pain that he became addicted to heavy analgesics. He had gastric crises, and later complications in the form of pyelonephritis and diabetes mellitus. Kidney failure was determined as the official cause of death.

Joe 'Fox' Smith (June 28, 1902 - December 2, 1937) was an American jazz musician, a famous trumpet and cornet player ${ }^{10}$. He was born to a family with six brothers, all of whom were musicians. While there is no definitive evidence that he contracted syphilis, it is historically documented that he was lecherous polygamist, thus being a fitting target for the infection. According to some studies, polygamy is often the leading cause of syphilis in societies where it is widely practiced $^{11}$. Also, towards the end of his life, symptoms of progressive paralysis, i.e. general paresis emerged, which also indicates syphilitic infection. He was one of the many jazz musicians who were alcoholics and possibly heavy drug abusers. At the age of only 35 , he died from complications of tuberculosis in an asylum in New York.

Leon Joseph Roppolo (March 16, 1902 - October 5, 1943) was a prominent early jazz clarinetist and saxophonist ${ }^{10}$. As opposed to the collective improvisation of most New Orleans bands, he was a pioneer of the jazz solo. He became famous in the early 1920s by playing with the New Orleans Rhythm Kings, one of the most popular jazz bands at the time. Privately, he was a heavy alcohol abuser and had increasingly pronounced symptoms of paranoid psychosis. He contracted syphilis early, and it progressed to progressive paralysis. Due to worsening of the symptoms, in 1925 he was hospitalized in a mental hospital. Although he continued to play and work, he spent most of the rest of his life in a hospital, where he died in 1943.

Lester Willis Young (August 27, 1909 - March 15, 1959) was a famous jazz musician ${ }^{10}$. Due to his virtuoso saxophone playing, legendary jazz singer Billie Hol- iday nicknamed him 'Pres' or 'Prez' (president). In contrast to most other saxophonists at the time, he developed a light and airy sound. He was an alcohol abuser infected with syphilis, but his disease was in latent stage. In his last years, he started to drink more and more, and was eating less, so he suffered from liver disease and malnutrition. Due to his weakness, he had to sit during performances, except during his solo parts. His condition further deteriorated during European tour in 1959, when he exhausted himself and was drinking heavily. Although he also had coronary problems, he finally died from esophageal hemorrhage as a consequence of liver cirrhosis after return from the tour to New York.

Charles 'Bird' Parker, Jr. (August 29, 1920 - March 12,1955) was an American jazz saxophonist and composer ${ }^{10}$. He was one of the leading figures responsible for the development of bebop in the early to mid1940s, a style of jazz characterized by fast tempos and virtuoso playing. He was alcohol and heavy drug abuser with consequential liver cirrhosis. Addiction to heroin greatly affected his work, causing him to miss performances ever more often, and it also made him mentally unstable. Additionally, alcohol addiction and poor dietary habits made him losing weight and become physically weak. Medical records confirm that he also had syphilis, confirmed by positive Wasserman reaction, and was treated for the infection. Over time, he developed psychotic decompensation, probably as a consequence of neurosyphilis-progressive paralysis. He died in New York in 1955. Lobar pneumonia and bleeding ulcer were listed as the cause of death, although he had decompensated stage of liver cirrhosis, and had suffered a heart attack.

\section{Other musicians}

Several non-American famous musicians also had neurosyphilis-progressive paralysis (F.T.A. Delius ${ }^{12-14}$, G.R. Sinclair, G.L.P. Spontini ${ }^{15}$, E.T.A. Hoffmann ${ }^{15}$, D.G.M. Donizetti ${ }^{15}$, F.P. Schubert ${ }^{16,17}$, M.I. Glinka ${ }^{18}$, R. Schumann ${ }^{19}$, B. Smetana ${ }^{20}$, A.E. Chabrier, and H. Wolf ${ }^{21}$ ), as shown in Table 1. According to the symptoms described and literature available, neurosyphilitics were some other, less famous musicians too, i.e. Czech composer Josef Mysliveček (March 9, 1737 February 4, 1781); German impresario, dramatist, actor, singer and composer Emanuel Schikaneder (September 1, 1751 - September 21, 1812); Russian com- 
Table 1. Other famous musicians who died of neurosyphilis including other known medical conditions they suffered during lifetime

\begin{tabular}{|c|c|c|c|}
\hline Musician & Date of birth and death & Home country & Other medical conditions \\
\hline $\begin{array}{l}\text { Frederick Theodore } \\
\text { Albert Delius }\end{array}$ & January 29, 1862 - June 10, 1934 & England & Blindness \\
\hline $\begin{array}{l}\text { George Robertson } \\
\text { Sinclair }\end{array}$ & October 28, 1863 - February 7, 1917 & England & Psychosis \\
\hline $\begin{array}{l}\text { Gaspare Luigi } \\
\text { Pacifico Spontini }\end{array}$ & November 14, 1974 - January 24, 1851 & Italy & Deafness \\
\hline $\begin{array}{l}\text { Ernst Theodor } \\
\text { Amadeus Hoffmann }\end{array}$ & January 24, 1776 - June 25, 1822 & Germany & / \\
\hline $\begin{array}{l}\text { Domenico Gaetano } \\
\text { Maria Donizetti }\end{array}$ & November 29, 1797 - April 8, 1848 & Italy & $\begin{array}{l}\text { Urinary infection, myelitis, } \\
\text { stroke }\end{array}$ \\
\hline Franz Peter Schubert & January 31, 1797 - November 19, 1828 & Austria & Delirium, typhus \\
\hline $\begin{array}{l}\text { Mikhail Ivanovich } \\
\text { Glinka }\end{array}$ & June 1, 1804 - Februrary 15, 1857 & Russia & Neurosis, alcoholism, delirium \\
\hline Robert Schumann & June 8,1810 - July 29, 1856 & Germany & $\begin{array}{l}\text { Schizoaffective psychosis, } \\
\text { alcoholism, hypertension }\end{array}$ \\
\hline Bedrich Smetana & March 2, 1824 - May 12, 1884 & Czech Republic & Deafness \\
\hline $\begin{array}{l}\text { Alexis Emmanuel } \\
\text { Chabrier }\end{array}$ & January 18, 1841 - September 13, 1894 & France & Dysgraphia, dysphasia \\
\hline Hugo Wolf & March 13, 1860 - February 22, 1903 & Austria & $\begin{array}{l}\text { Hallucinations, paranoid } \\
\text { syndrome, pneumonia }\end{array}$ \\
\hline
\end{tabular}

poser Alexander Lwowitsch Guriljow (August 22, 1803 - August 30,1858); French composer and musicologist Juste-Adrien-Lenoir de La Fage (March 28, 1801 - March 8, 1862); Italian composer Luigi Ricci (July 8, 1805 - December 31, 1859); French conductor and composer Louis-Antoine Jullien (April 23, 1812 - March 14, 1860); Croatian painter and flute- and guitar-player Vjekoslav Karas (May 19, 1821 - July 5, 1858); Italian pianist, conductor and composer Carlo Andreoli (1840 - 1908); Polish composer and pianist Eugeniusz Pankiewicz (December 15, 1857 - December 24, 1898); and Hungarian composer Paul Abraham (November 2, 1892 - May 6, 1960) 22-25. All of them contracted syphilis at a young age.

\section{Discussion}

Most of famous jazz musicians pursued lifestyle characterized by drug and alcohol abuse, and sexual promiscuity, leading to infectious diseases such as syphilis, tuberculosis, and chronic viral hepatitis as the consequence of their risky lifestyle. As noted by Sar- $\operatorname{tin}^{26}$, while it is difficult to separate the influence of lifestyle from the social effects of poverty and nomadic existence, the ubiquitous nature of drug and alcohol abuse among these musicians is undeniable. Thus, famous classical composers and jazz musicians were more prone to be infected than the general population due to their liberal and dynamic lifestyle. Syphilis was rampant during that period, and prostitutes were the carriers. The myth of femme fatale or 'poison women' of the $19^{\text {th }}$ century is believed to be partly derived from the devastation of syphilis. Contrary to these findings, a statistical study of 86 jazz musicians by Spencer refutes the statement regarding premature death in this population. Jazz musicians reported in his study did not die young; however, the size and sex distribution of the sample limited strong conclusions, as stated in the article ${ }^{27}$.

Syphilis is a systemic disease caused by the spirochete bacterium T.pallidum. Newly published evidence suggests that the hypothesis supporting the theory of the American origin of the disease ('Columbian theory') is the valid one. In the present study, 1500 patho- 
graphies of famous musicians and composers were analyzed. Among them, ten Anglo-American composers and jazz musicians who suffered from neurosyphilis (tertiary stage of the disease), as well as eleven other famous and ten less known composers who died of neruosyphilis-progressive paralysis, were extracted for this report. It yielded a figure of 31 analyzed composers-neurosyphilitics in this article. In the group of Anglo-American composers, most of them died from progressive paralysis while still being in their creative phase of life, leaving their talent only partially expressed. Neurosyphilis occurs when T. pallidum affects the central nervous system (brain and/or spinal cord). This tertiary stage of the disease can cause serious neurological damage, including paralysis (as documented in the vast majority of the composers and musicians analyzed), numbness, gradual blindness (as in F.T.A. Delius) and deafness (as in G.L.P. Spontini and B. Smetana), as well as permanent disability or death. Thus, even in cases where the disease did not cause premature death, it could cause serious disability, which in turn prevented further work and skill improvement.

\section{References}

1. Kent ME, Romanelli F. Reexamining syphilis: an update on epidemiology, clinical manifestations, and management. Ann Pharmacother. 2008;42:226-36, http://dx.doi.org/10.1345/aph.1K086

2. Farhi D, Dupin N. Origins of syphilis and management in the immunocompetent patient: facts and controversies. Clin Dermatol. 2010;28:533-8, http://dx.doi.org/ 10.1016/j.clindermatol.2010.03.011

3. Armelagos GJ, Zuckerman MK, Harper KN. The science behind pre-Columbian evidence of syphilis in Europe: research by documentary. Evol Anthropol. 2012;21:50-7, http://dx.doi.org/10.1002/evan.20340

4. Hegarty ME. Sex, sin, and science: a history of syphilis in America (review). Bull Hist Med. 2009;83:779-80, http://dx.doi.org/10.1353/bhm.0.0273

5. Konjević-Pernar S, Bednar I, Novak-Laus K, Petric-Vicković I, Mandić Z. Bilateral optic neuritis as initial manifestation of neurosyphilis in a HIV-positive patient. Acta Clin Croat. 2008;47(2):97-100.

6. Mapelli G. Must we revise our clinical concepts of tabetic neurosyphilis? Acta Neurol Belg. 1981;81(1):12-23.

7. Levy AH. Edward MacDowell: An American Master. Lanham, Md: Scarecrow Press; 1998.
8. Page EF. Edward MacDowell: His Work and Ideals. New York: Dodge; 1910.

9. Schwab AT. Edward MacDowell's Mysterious Malady. Musical Quarterly. 2006;89(1):136-51.

10. Spencer FJ. Jazz and Death: Medical Profiles of Jazz Greats. Jackson: University Press of Mississippi; 2002.

11. Bello CS, Elegba OY, Dada JD. Sexually transmitted diseases in northern Nigeria. Five years' experience in a university teaching hospital clinic. Br J Vener Dis. 1983;59(3):202-5.

12. Beecham T. Frederick Delius. London: Hutchinson \& Co.; 1959.

13. Carley L. Delius: A Life in Letters, 1862-1908, Vol.1. Harvard University Press: Cambridge; 1983.

14. Jefferson A. Delius (The Master Musicians Series, ed. J. Westrup). New York: Octagon Books; 1881.

15. Breitenfeld T, Vodanović M, Breitenfeld D, et al. Spontini, Hoffman, Donizetti, MacDowell, Delius and other composers neurosyphilitics. Alcoholism. 2009;45:143-52.

16. Andersen SN. Franz Schubert: His Life, Music and Diseases. Tidsskr Nor Laegeforen. 2000;120:1991-4.

17. Bevan PG, Rold RL. Schubert and syphilis. J Med Biogr. 1996;4(3):184-5, http://dx.doi.org/10.1177/096777209600400312

18. Breitenfeld D, Thaller V, Kereković M, Grubišić V, Breitenfeld T, Jagetić N. Mikhail Ivanovich Glinka (1804-1857). Pathography. Alcoholism. 2007;43:127-33.

19. Breitenfeld D, Thaller V, Bergovec M, et al. Pathography of famous musicians. Robert Schumann (1810-1856). Pathography. Alcoholism. 2004;40:75-9.

20. Breitenfeld T, Vargek Solter V, Breitenfeld D, Demarin V. Bedrich Smetana - a pathography on the $180^{\text {th }}$ anniversary of his birth and $120^{\text {th }}$ anniversary of his death. Eur J Neurol. 2004; 11:181.

21. Breitenfeld T, Thaller V, Jagetić N, Bergovec M, Breitenfeld D, Kosan M. Hugo Wolf (1860-1903). Pathography. Alcoholism. 2006;42:101-4.

22. Springer B. Die genialen Syphilitiker. Berlin: Harsch; 1926. (in German).

23. Roos KL. Neurosyphilis in musicians and composers. Semin Neurol. 1999;19:35-40.

24. Boehme G. Medizinische Portraits beruehmter Komponisten. Stuttgart: Fischer; 1981. (in German).

25. Lange-Eichbaum W, Kurth W, Ritter W. Genie, Irrsinn und Ruhm. Die Komponisten. München: Reinhardt; 1986. (in German).

26. Sartin JS. Contagious rhythm: infectious diseases of $20^{\text {th }}$ century musicians. Clin Med Res. 2010;8(2):106-13, http://dx.doi.org/10.3121/cmr.2010.882

27. Spencer FJ. Premature death in jazz musicians: fact or fiction? Am J Public Health. 1991;81(6):804-5. 
Sažetak

NEUROSIFILIS KOD ANGLOAMERIČKIH SKLADATELJA I JAZZ GLAZBENIKA

D. Breitenfeld, D. Kust, T. Breitenfeld, M. Prpić, M. Lucijanić, D. Zibar, V. Hostić, M. Franceschi i A. Bolanča

Sifilis je spolno prenosiva, sistemska bolest uzrokovana spirohetnom bakterijom Treponema pallidum. Najčešći način prijenosa bolesti je spolni odnos. Iako ima više hipoteza, točno podrijetlo bolesti još je uvijek nepoznato. Nedavno objavljeni podaci pokazuju da je najvjerojatnije točna hipoteza koja podupire teoriju američkog podrijetla bolesti. Među 1500 analiziranih patografija skladatelja i glazbenika za ovaj prikaz izdvojeni su podaci o deset angloameričkih skladatelja i jazz glazbenika koji su bolovali od neurosifilisa (tercijarni stadij bolesti). U analiziranoj skupini angloameričkih skladatelja i glazbenika većina ih je umrla od progresivne paralize dok su još uvijek bili u kreativnoj fazi života. Dodatno, ukratko su prikazane dijagnoze jedanaestorice drugih slavnih skladatelja neurosifilitičara te također osnovni biografski podaci desetorice manje poznatih skladatelja koji su umrli od neurosifilisa odnosno progresivne paralize. U zaključku, neurosifilis može uzrokovati značajno neurološko oštećenje, a u težim slučajevima također dovesti do trajnog invaliditeta ili smrti i time spriječiti daljnji rad i profesionalni razvoj.

Ključne riječi: Glazbenici; Neurosifilis; Povijest; Glazba; Biografija kao tema; Patologija 